\title{
Effect of Competition and Climatic Conditions on the Growth of Beech in the Mixed Pine Beech Stand: Lithuanian Case Study ${ }^{\dagger}$
}

\author{
Edgaras Linkevičius * and Gerda Junevičiūtè
}

Citation: Linkevičius, E.; Junevičiūtè,

G. Effect of Competition and

Climatic Conditions on the Growth of Beech in the Mixed Pine Beech Stand: Lithuanian Case Study. 2021 3, 49. https://doi.org/10.3390/ IECF2020-07961

Academic Editors: Angela Lo Monaco, Cate Macinnis-Ng and Om P. Rajora

Published: 12 November 2020

Publisher's Note: MDPI stays neutral with regard to jurisdictional claims in published maps and institutional affiliations.

Copyright: $₫ 2020$ by the authors. Licensee MDPI, Basel, Switzerland. This article is an open access article distributed under the terms and conditions of the Creative Commons Attribution (CC BY) license (http://creativecommons.org/licenses /by/4.0/).
Agriculture Academy, Faculty of Forest Sciences and Ecology, Vytautas Magnus University, Studentu 13, Akademija, LT-53362 Kaunas dstr, Lithuania; Gerda.Juneviciute@stud.vdu.lt

* Correspndence: Edgaras.Linkevicius@vdu.lt

† Presented at the 1st International Electronic Conference on Forests - Forests for a Better Future: Sustainability, Innovation, Interdisciplinarity, 15-30 November 2020; Available online: https://iecf2020.sciforum.net.

\begin{abstract}
Climate change and warming will potentially have profound effects on forest growth and yield, especially for pure stands in the near future. Thus, increased attention has been paid to mixed stands, e.g., pine and beech mixtures. However, the interaction of tree species growing in mixtures still remains unknown. Thus, the aim of this study was to investigate the impact of the interspecific and intraspecific competition to diameter, height, and crown width of pine and beech trees growing in mixtures, as well as to evaluate the impact of climatic indicators to the beech radial diameter increment. The data was collected in 2017 at the mixed mature pine beech double layer stand, located in the western part of Lithuania. The sample plot of 1.2 hectare was established and tree species, diameter at the breast height, tree height, height-to-crown base, height-to-crown width, and position were measured for all 836 trees. Additionally, a representative sample of radial diameter increments were estimated only for the beech trees by taking out core discs at the height of $1 \mathrm{~m}$ when the stand was partially cut. Competition analysis was based on the distance-dependent competition index, which was further based on crown parameters. Climatic effect was evaluated using classification and regression tree (CART) analysis. We found almost no interspecific competition effect to diameter, height, or crown width for both tree species growing in the first layer. However, it had an effect on beeches growing in the second layer. The intraspecific competition effect was important for pine and beech trees, showing a negative effect for both of them. Our results show the possible coexistence of these tree species due to niche differentiation. An analysis of climatic indicators from 1991-2005 revealed that precipitation from February-May of the current vegetation year and mean temperatures from July to September expressed radial diameter increment effects for beech trees. Low temperatures during March and April, as well as high precipitation during January, had a negative effect on beech radial increments. From 20062016, the highest effect on radial diameter increments was the mean temperatures from July to September, as well as the precipitation in January of the current year. From 1991-2016, the highest effect on radial diameter increments was the temperature from July to September 1991-2016 and the precipitation in June 1991-2016. Generally, cool temperatures and higher precipitation in June had a positive effect on beech radial increments. Therefore, our results show a sensitivity to high temperatures and droughts during summer amid Lithuanian's growth conditions.
\end{abstract}

Keywords: interspecific competition; intraspecific competition; pine and beech mixtures; seasonal effects; climatic indicators; radial growth

\section{Introduction}

The effects of climate change and forest adaptation on future environmental conditions may significantly alter forestry practices around the world [1]. The promotion of mixed forests is related to an adaptation strategy in forest management used to cope with climate change [2]. Recent studies have shown that mixed stands can reach the same 
productivity as pure stands. Moreover, studies have shown higher productivities of mixed stands compare to pure stands [3,4]. Nevertheless, mixed-species stands may provide more forest functions and services compared to monocultures [5].

However, the management of mixed stands requires much more knowledge and skills. It is well known that not all tree species affect each other positively and can coexist together. Only species with an ecological niche differ from each other, e.g., light demanding pines and shade-tolerant tree species, such as beech trees, provide higher yields compared to pure stands [6].

Since the Atlantic distribution range of European beeches and more continental range of Scots pines overlap, mixed stands of pine and beech trees are of considerable importance in Europe [4]. For example, for more than two decades, forest conversion from pure pine stands to pine-beech or pine-oak mixtures has been a major objective for planning and management in Germany. As such, the importance of multi-storied stands in forestry practice has steadily increased [7].

Although remarkable research regarding pine beech mixtures has already been conducted, Pretzsch 2015 [4] highlighted the limited knowledge of the mixing effects between scots pine and European beech.

Thus, the aim of this study was to investigate the impacts of the interspecific and intraspecific competition to the diameter, height, and crown width of pine and beech trees growing in mixtures, as well as to evaluate the impact of climatic indicators on beech radial diameter increments.

\section{Methods}

The experimental plot of 1.2 hectare (length of 200 meters and width of 60 meters) was established in 2017. The data was collected in the mixed mature pine beech double layer stand, which is located in the western part of Lithuania. The age for pines-which was recorded from the stand wise forest inventory data-was 115 years and the age for beeches were 75 years. Experimental sites belonged to the Pinetum Vaccinio-myrtillosa forest type with moderately dry and comparatively fertile oligotrophic mineral soils, i.e., Haplic Arenosol, where the water table is deeper than $5 \mathrm{~m}$ and suitable for pine growth.

The tree species, diameter at breast height, tree height, height-to-crown base, height-to-crown widths, and position were measured for all 836 trees. Additionally, representative sample of the radial diameter increments were estimated only for beech trees by taking out core discs at the height of $1 \mathrm{~m}$ when the stand was partially cut. In total, core discs were taken for 76 trees, and the radial diameter increments for each sample were measured two times, according to North and East directions, which were marked in the field for each disc. Thus, 152 measurements were available for study. Measurements were done using the LINTAB 6 estimation system and a program package WinTSAP 0.30

The synchronization of annual rings increments was done using the TSAP-Win program. The asynchronous annual rings were tested and remeasured.

The competition analysis was based on the distance-dependent competition index. The competitors for each tree were identified by setting the inverse search cone with opening angle of 80 degrees on the crown base of the target tree [7]. The competition index proposed by Pretsch 1995 [8], which incorporated horizontal crown areas, was used to estimate competition values. Interspecific and intraspecific competition indices were calculated using the CroCom analytical program, which was developed by TU Dresden scientists [7].

Interspecific competition was estimated by taking different tree species that appeared in the search cone of a target tree. Accordingly, intraspecific competition was calculated by taking the same tree species trees that appeared inside of a search cone.

We investigated the effect of climatic indicators on beech radial diameter increments from 1991 to 2016. Climatic indicators are as follows: mean monthly temperatures and mean monthly precipitations from 1991-2016. Climatic data was obtained from the clos- 
est Jurbarkas meteorology station that belongs to the Lithuanian hydrometeorology service. This station was located about $25 \mathrm{~km}$ away from the research plot.

In order to eliminate the age impact on radial diameter increments, radial diameter increment indices were estimated using the Stravinskiene (2002) method [9]. According to this method, all analyzed periods were divided into 5 years intervals. For these intervals, mean radial diameter increments were estimated. Finally, radial diameter increments from 1991-2016 was divided by the 5 years mean radial diameter increment. An analysis of climatic indicators was done using classification and regression trees (CART) analysis implemented in the STATISTICA 10 program.

\section{Results and Discussion}

\subsection{Productivity}

The main yield characteristics of the analyzed stands are presented in Table 1 . The two layered stands were mainly composed from 115 year old pine trees (about $70 \%$ in the first layer) and 75 year old beech trees (30\% in the first layer and $100 \%$ in the second layer). Moreover, other trees species such as birch, oak, and spruce were found in the stand, yet their proportions were only minor.

It is important to note that this mixed stand was highlighted for its productivity. The growing volume of pines was $392 \mathrm{~m}^{3} / \mathrm{h}$. However, the growing volume of beech trees in the first layer was $144 \mathrm{~m}^{3} / \mathrm{h}$ and in the second it was $78 \mathrm{~m}^{3} / \mathrm{ha}$. The total productivity of the stand was $659 \mathrm{~m}^{3} / \mathrm{ha}$.

Table 1. Main yield characteristics of the investigated mixed stand.

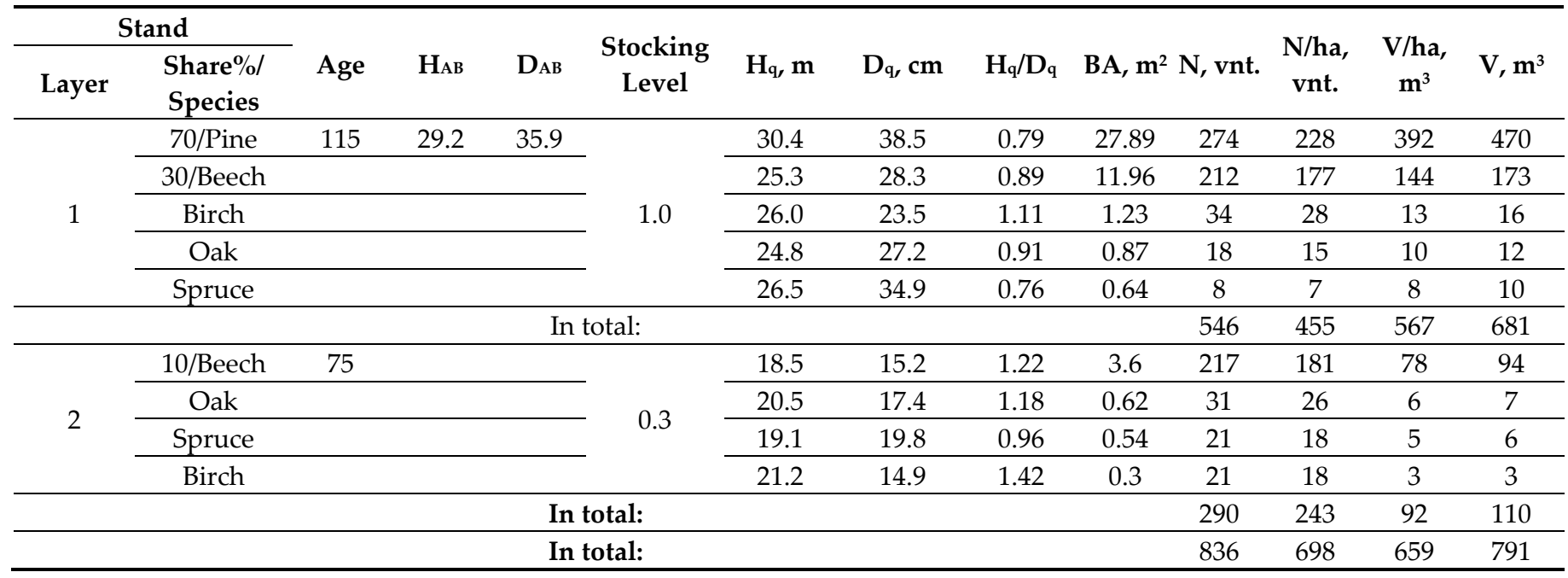

* The $\mathrm{H}_{\mathrm{AB}-\mathrm{site}}$ index: mean height at the base age of 100 years for pines in $\mathrm{m}$; $\mathrm{D}_{\mathrm{AB}}$-site index: quadratic mean diameter at the base age of 100 years for pines in cm; $\mathrm{H}_{\mathrm{q}}$ : mean height in $\mathrm{m}$; Dq: quadratic mean diameter in $\mathrm{cm}^{2}$; BA: basal area in $\mathrm{m}^{2}$; $\mathrm{N}$ : number of trees; V: growing volume in $\mathrm{m}^{3}$.

The impacts of interspecific and intraspecific competition on diameter height and crown width of the trees were found to have almost no effect for both tree species growing in the first layer. The $\mathrm{R}^{2}$ (coefficient of determination values) between the interspecific competition and diameter at breast height, tree height, and crown width did not reach more than 0.2 and the relations were insignificant $(p>0.05)$. However, interspecific competition had an effect on beeches growing in the second layer. The asymmetric competition from pines had a significant negative effect on diameter, height, and crown width of beech trees.

The intraspecific competition had significant negative effects on diameter at breast height, as well as height and crown widths for both pines and beech trees. Both grew in the first and second layers $\left(R^{2}>0.33\right)$. 


\subsection{Climatic Trends from 1991 to 2016 in Jurbarkas}

The mean annual temperature from 1991 to 2016 increased approximately by $1{ }^{\circ} \mathrm{C}$, then from 7 to $8{ }^{\circ} \mathrm{C}$ with a yearly increase of approximately by $0.0625^{\circ} \mathrm{C}$. However, the mean annual precipitation during the analyzed period remained the same and fluctuated around $800 \mathrm{~mm}$ per year (data taken from the Jurbarkas meteorology station).

The impact of climatic variables on beech trees radial increments revealed that, from 1991-2005, more than $48.5 \mathrm{~mm}$ precipitation from February-May had a positive effect on the radial growth of beech trees. Moreover, the mean temperatures from July to September lowered to $16.5^{\circ} \mathrm{C}$. On the contrary, temperatures lower than $5.2^{\circ} \mathrm{C}$ in March and April, as well as high precipitation rates $(62.8 \mathrm{~mm})$ in January, had negative effects on beech radial increments.

The analysis of climatic indicators from 2006-2016 revealed that the highest radial increment was achieved when mean temperatures from July to September were lower than $16.5^{\circ} \mathrm{C}$ and precipitation in January was more than $62.8 \mathrm{~mm}$.

The highest radial diameter increment from 1991-2016 was found when the mean temperatures from July-September were lower than $16.3^{\circ} \mathrm{C}$ and the precipitation rates in June were lower than 74.7 degrees.

Generally, cool temperatures and higher precipitation rates in June had a positive effect on beech radial increments. This shows its sensitivity to high temperatures and droughts during summer in Lithuania.

\section{References}

1. Bernier, P.; Schoene, D. Adapting forests and their management to climate change: An overview. Unasylva 2009, 60, 5-11.

2. Bolte, A.; Ammer, C.; Löf, M.; Madsen, P.; Nabuurs, G.-J.; Schall, P.; Spathelf, P.; Rock, J. Adaptive forest management in central Europe: climate change impacts, strategies and integrative concept. Scand. J. For. Res. 2009, 24, 473-482.

3. Del Rio, M.; Pretzsch, H.; Alberdi, I.; Bielak, K.; Bravo, F.; Brunner, A.; Condés, S.; Ducey, M.J.; Fonseca, T.; von Lüpke, N.; et al. Characterization of the structure, dynamics, and productivity of mixed-species stands: review and perspectives. Eur. J. For. Res. 2016, 135, 23-49.

4. Pretzsch, H.; del Río, M.; Ammer, C.; Avdagic, A.; Barbeito, I.; Bielak, K.; Brazaitis, G.; Coll, L.; Dirnberger, G.; Drössler, L.; et al. Growth and yield of mixed versus pure stands of Scots pine (Pinus sylvestris L.) and European beech (Fagus sylvatica L.) analysed along a productivity gradient through Europe. Eur. J. For. Res. 2015, 134, 927-947.

5. Gamfeldt, L.; Snäll, T.; Bagchi, R.; Jonsson, M.; Gustafsson, L.; Kjellander, P.; Ruiz-Jaen, M.C.; Fröberg, M.; Stendahl, J.; Philipson, C.D.; et al. Higher levels of multiple ecosystem services are found in forests with more tree species. Nat. Commun. 2013, 4, doi:10.1038/ncomms2328.

6. Pretzsch, H. Forest Dynamics, Growth and Yield: from Measurement to Model; Springer: Berlin, Heidelberg, 2010; ISBN 9783540883067.

7. Schröder, J.; Röhle, H.; Gerold, D.; Münder, K. Modeling individual-tree growth in stands under forest conversion in East Germany. Eur. J. For. Res. 2007, 126, 459-472, doi:10.1007/s10342-006-0167-x.

8. Pretzsch, H. Zum Einfluß des Baumverteilungsmusters auf den Bestandeszuwachs. Allg. Forst Jagdztg. 1995, 166, $190-201$.

9. Juknys, R.; Stravinskiene, V.; Vencloviene, J. Tree-ring analysis for the assessment of anthropogenic changes and trends. Environ. Monit. Assess. 2002, 77, 81-97. 